\section{Plastic toy soldiers, a lost battle? \\ - an analytical perspective}

\section{Soldadinhos de plástico, uma batalha perdida? - uma perspetiva analítica}

\author{
ANTÓNIO PEREIRA ${ }^{1,2,4}$ \\ ANTÓNIO CANDEIAS ${ }^{1,2}$ \\ ANA CARDOSO ${ }^{1}$ (1) \\ JOSÉ MIRÃO ${ }^{1}$ \\ ANA TERESA CALDEIRA ${ }^{1,2}$
}

1. HERCULES Laboratory and CityUMacau Chair on Sustainable Heritage, Institute for Advanced Studies and Research of Évora University, Évora, Portugal 2. Chemistry Department, School of Sciences and Technology, Évora University, Évora, Portugal

*amlp@uevora.pt

\section{KEYWORDS}

Plastic objects

The preservation and conservation of museum collections requires a detailed understanding
of their constituent materials. The use of a wide variety of instrumental techniques can provide complementary data regarding the composition and structure of these materials. A set of plastic toy soldiers (mid 2oth century) from the Oporto Military Museum (Museu Militar do Porto) exibited accelerated deterioration. To better understand this deterioration process, the authors used a multi-analytical approach. The micromorphological features of the objects were characterized with stereoscopic microscopy and VP-SEM-EDS, the polymer and its additives were identified with ATR-FTIR, and $1 \mathrm{H}$ and $13 \mathrm{C}$ NMR, respectively, and the crystalline degradation products were identified with micro-XRD. The polymer that composes the toys was identified as cellulose acetate, with triphenyl phosphate and dimethyl phthalate additives. A crystalline efflorescence of triphenyl phosphate was identified as a degradation product. This methodology showed to be adequate for a detailed characterization of plastic artefacts in museum environments.

\section{Resumo}

A preservação e a conservação de coleções em museus requer o conhecimento dos seus materiais constituintes. $\mathrm{O}$ uso de variadas técnicas instrumentais pode fornecer resultados complementares sobre a composição e estrutura destes materiais. Um conjunto de soldadinhos de plástico (de meados do século XX) do Museu Militar do Porto apresentava um processo de deterioração acelerado. Para melhor compreender essa deterioração, os presentes autores utilizaram uma abordagem multi-analítica. A micromorfologia dos objectos foi caracterizada através de microscopia estereoscópica e microscopia eletrónica de varrimento de pressão variável (VP-SEM-EDS), o polímero e seus aditivos foram identificados por espectroscopia de infravermelho com transformada de Fourier com reflexão total atenuada (ATR-FTIR) e ressonância magnética nuclear (1H e 13C RMN), respectivamente, e os produtos de degradação com estrutura cristalina foram identificados por microdifração de raios X (Micro-XRD). O polímero que contitui os soldadinhos foi identificado como acetato de celulose, tendo fosfato de trifenilo e ftalato de dimetilo como principais aditivos, e as eflorescências cristalinas foram idenficadas como fosfato de trifenilo. Esta metodologia mostrou-se adequada para uma caracterização detalhada de artefactos de plástico em ambiente museológico.
Multi-analytical method

Cellulose acetate

Triphenyl phosphate

Dimethyl phthalate

\section{PALAVRAS-CHAVE}

Artefactos plásticos Estudo multi-analítico Acetato de celulose Fosfato de trifenilo Ftalato de dimetilo 


\section{Introduction}

Nowadays, plastics, a mixture of polymers and other substances added to improve their properties [1-2] are extensively present in numerous modern art museum collections worldwide. Unfortunately, many man-made mouldable polymeric materials are relatively short-living compared to other materials found in historical collections, such as wood, stone, parchment, paper and bone. Whereas the ageing and degradation of a plastic artefact in non-museum circumstances can be tackled through replacement, degradation in a heritage context takes with it the importance of originality and cultural significance.

In the specific case of plastic objects present in museum collections, the symptoms of initial degradation in this type of objects are not fully recognized until the first visible signs of advanced stage of degradation occur, such as changes in colour and gloss, shrinkage, deformation and the appearance of cracks [3]. Plastic degradation, once initiated, cannot be prevented, stopped or reversed, but sometimes it may be slowed down. The technological advances in several areas used to characterize this type of materials, do not yet allow to predict or determine their stability along the time in a museum environment [4].

Physical, chemical and biological factors, alone or together, can contribute to the plastic accelerated degradation. Physical factors mainly involve the migration of the additives, besides the environment interactions that can cause brittleness or warping. Chemical factors, due to the interactions of plastic with oxygen, ozone, water, air pollutants and radiation, can cause severe changes to the polymer matrix or their additives, causing a great number of physical alterations in them and ultimately leading to their total degradation [5]. The biodeterioration promoted by microorganisms, especially fungi and bacteria that develop in the museum environments, causes severe surface alterations in the objects, causing stains or colour changes, leaving characteristic odour or even penetrating in the polymeric matrix, leading to their total decomposition [6-9].

The accelerated degradation of plastic artefacts in museums also raises concerns about public health and indoor pollution. The acidic by-products produced during cellulose acetate and cellulose nitrate degradation and the emission and migration of toxic additives, are examples to consider [10-16]. Besides their adverse health effect, the acidic by-products and the emitted additives are potentially hazardous to nearby artefacts, because they act as catalysts in the degradation processes [17-19].

The detailed characterization and identification of plastics in museum context, is therefore essential to evaluate the longevity of this kind of materials, which will allow to establish adequate storage conditions and to inform correct conservation practices [4, 20-21].

Several instrumental analytical techniques can be been used to identify and characterize polymers and their additives, such as pyrolysis-gas chromatography-mass spectrometry (Py-GC-MS), vibrational spectroscopy (FTIR or Raman) and nuclear magnetic resonance (NMR) [1, 22-24]. Preferably, the characterization methods should be non-destructive or minimum invasive for the objects to be analysed and whenever possible executed in situ since many objects cannot be transported out of the museum collection because of their size or for safety reasons. Techniques with quick response times and ease of use facilitate routine analysis of objects prior to conservation treatment [21, 25-26]. Nevertheless, the choice of complementary analytical techniques and number of analysis is frequently dependent on laboratory equipment facilities and research budgets.

This research was prompted by an urgent call from the Oporto Military Museum regarding a severe degradation process of a set of painted plastic toy soldier figurines (more than $10 \%$ ) dating to the middle of the twentieth century.

The manufacture of injection-moulded cellulose acetate toys was common, and previous studies have shown that this kind of material suffers several complex deterioration processes in the course of time [4, 20, 22, 27-28].

The fast degradation of cellulose acetate is due to the possible release of acetic acid, diphenyl phosphate and phenol [29]. Diphenyl phosphate is a strong acid that can catalyse the deacetylation of cellulose acetate [30].

For the study of their material and degradation/alteration products an analytical procedure was set up, compromising always as possible minimum-invasive and non-destructive techniques. A combination of stereoscopic microscopy, VP-SEM-EDS, Micro-XRD, $1 \mathrm{H}$ and $13 \mathrm{C}$ NMR and in situ ATR-FTIR was used to identify and characterize the polymeric matrix and their additives, as well as crystalline efflorescence present on the surface of the toys.

\section{Experimental}

\section{Toy soldier figurines}

The Oporto Military Museum houses one of the biggest collections of toy figurines with over 12500 pieces made of lead, plastic and wood chip paste. Among these, some of the 1200 plastic figurines from S.E.G.O.M. (Société d'Édition Générale d'Objets Moulés), made in the 50's-60's of the past century started to present visible degradation symptoms with cracking and crystalline efflorescence. These figurines with $5 \mathrm{~cm}$ heigth are all from the same period and type and were produced by injection molding in a single operation, being after painted. The figurines showcases have no temperature and humidity control nor other type of enviromental control (namely gas adsorbents/ filters). For the present research six solder figurines were selected for analysis (Figure 1), which presented different conservation condition, such as variable amount of crystallyne efflorescence, loss of surface painting, deformation and appearance of cracks. 

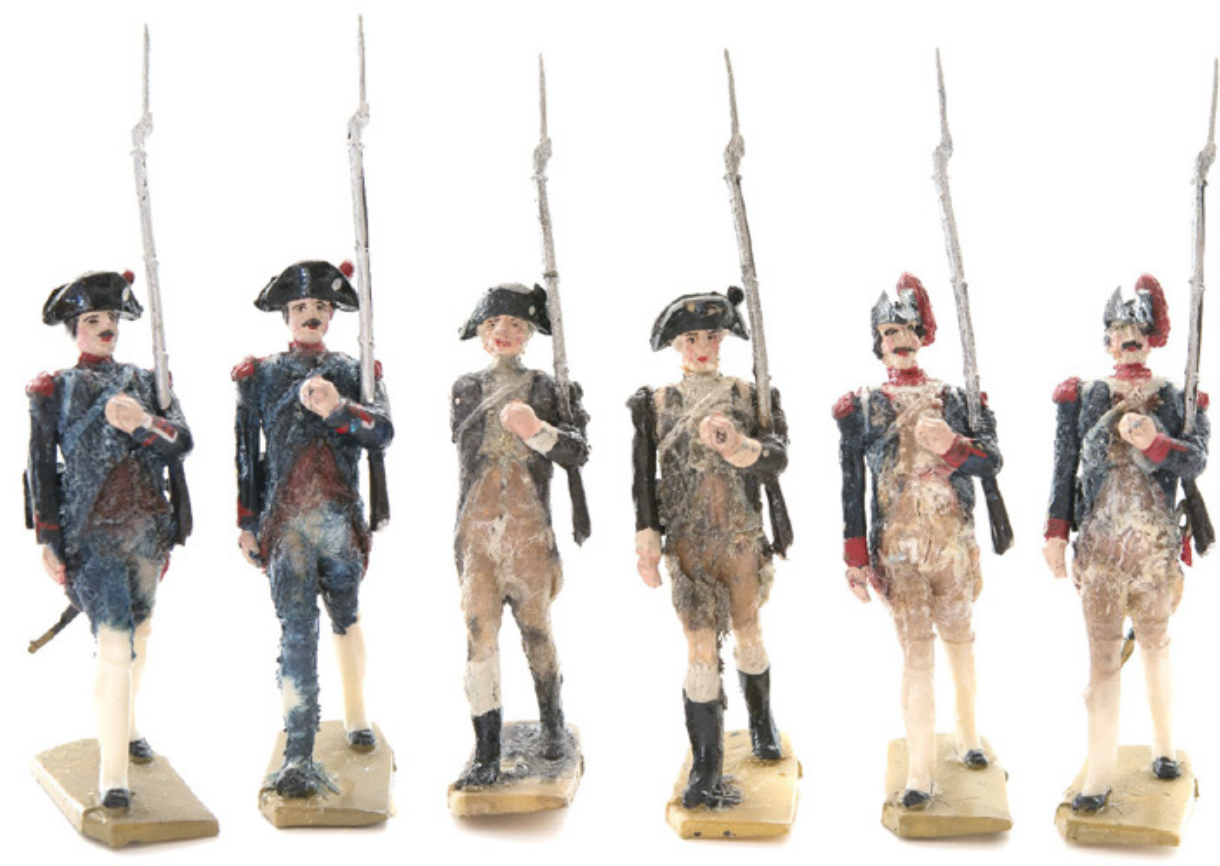

Figure 1. Example of the mid 2oth century, S.E.G.O.M. toy soldier figurines studied presenting severe degradation (average height: $5 \mathrm{~cm}$ ).

\section{Characterization}

To study these mid twentieth century plastic objects we envisaged a methodology that comprised the combination of optical microscopy and VP-SEM-EDS to recognize the micromorphology, ATR-FTIR to identify the polymer and NMR to identify the additives, and Micro-XRD to identify the crystalline efflorescence.

\section{Stereoscopic microscopy}

The soldier figurines were observed under a LEICA M205C stereozoom microscope to allow a deeper insight on some micromorphological features of the surface, such as the crystallyne efflorescence and depht of cracking.

\section{VP-SEM-EDS}

Variable Pressure Scanning Electron Microscopy coupled with Energy Dispersive X-ray Spectrometry (SEM-EDS) was employed for micromorphology characterization and elemental composition of crystallyne efflorescence. Toy soldier figurines were analysed without any preparation and sampling on a Hitachi S-3700N scanning electron microscope coupled with a Bruker XFlash 5010 SDD energy dispersive detector in variable pressure mode at $40 \mathrm{~Pa}$ and backscattering mode at operating conditions of $20 \mathrm{kV}$ accelerating voltage and $10 \mathrm{~mm}$ working distance.

\section{ATR-FTIR}

In situ Fourier Transform Infrared Spectroscopy was performed on an Alpha-R spectrometer from Bruker Optics, with an Attenuated Total Reflection (ATR) module, on the bottom of one figurine base that did not present any painting or coating, hence allowing the direct analysis of the plastic substrate. Bruker OPUS 6.5 software was used for processing the spectra. The IR spectra were plotted in the region between 4000 and $600 \mathrm{~cm}^{-1}$, with 128 scans and spectral resolution of $4 \mathrm{~cm}^{-1}$.

\section{Micro-XRD}

Micro-X-ray Diffraction ( $\mu$-XRD) was used for the identification of crystalline phases directly on one toy soldier figurine that presented severe crystallyne efflorescence, with no surface preparation, using a Bruker AXS D8 Discover micro-diffractometer with a one-dimensional Lynxeye detector, a Goebel mirror and a laser-video sample alignment system and motorized XYZ stage. Diffractograms were obtained in the range $5^{\circ}$ to $75^{\circ} 2 \theta$, with step size of $0.05^{\circ}$, with a recording time of $2 \mathrm{~s} \mathrm{per} \mathrm{step.} \mathrm{Diffraction} \mathrm{data}$ were registered using $\mathrm{Cu}$ Ka radiation at $40 \mathrm{kV}$ and $40 \mathrm{~mA}$, with the incident beam collimated to $1 \mathrm{~mm}$ diameter. For the identification of crystalline phase, the Bruker EVA software with International Centre for Diffraction Data Powder Diffraction Files (ICDD PDF) was used.

\section{NMR spectroscopy}

For the NMR analysis, two approaches were devised:

a) collection of detached efflorescence crystals (4-6 mg) from the toy soldier figurines and solubilisation in $1 \mathrm{~mL}$ of $99.96 \%$ deuterated methanol, $\mathrm{CD}_{3} \mathrm{OD}$ (Euriso-top, France);

b) preparation of solutions by the leaching technique. A small area of the object (typically $1 \mathrm{~cm}^{2}$ ) on the bottom of the figurine base (same area analysed by ATR-FTIR) was washed (percolated) with approximately $1 \mathrm{~mL}$ of $99.96 \%$ 

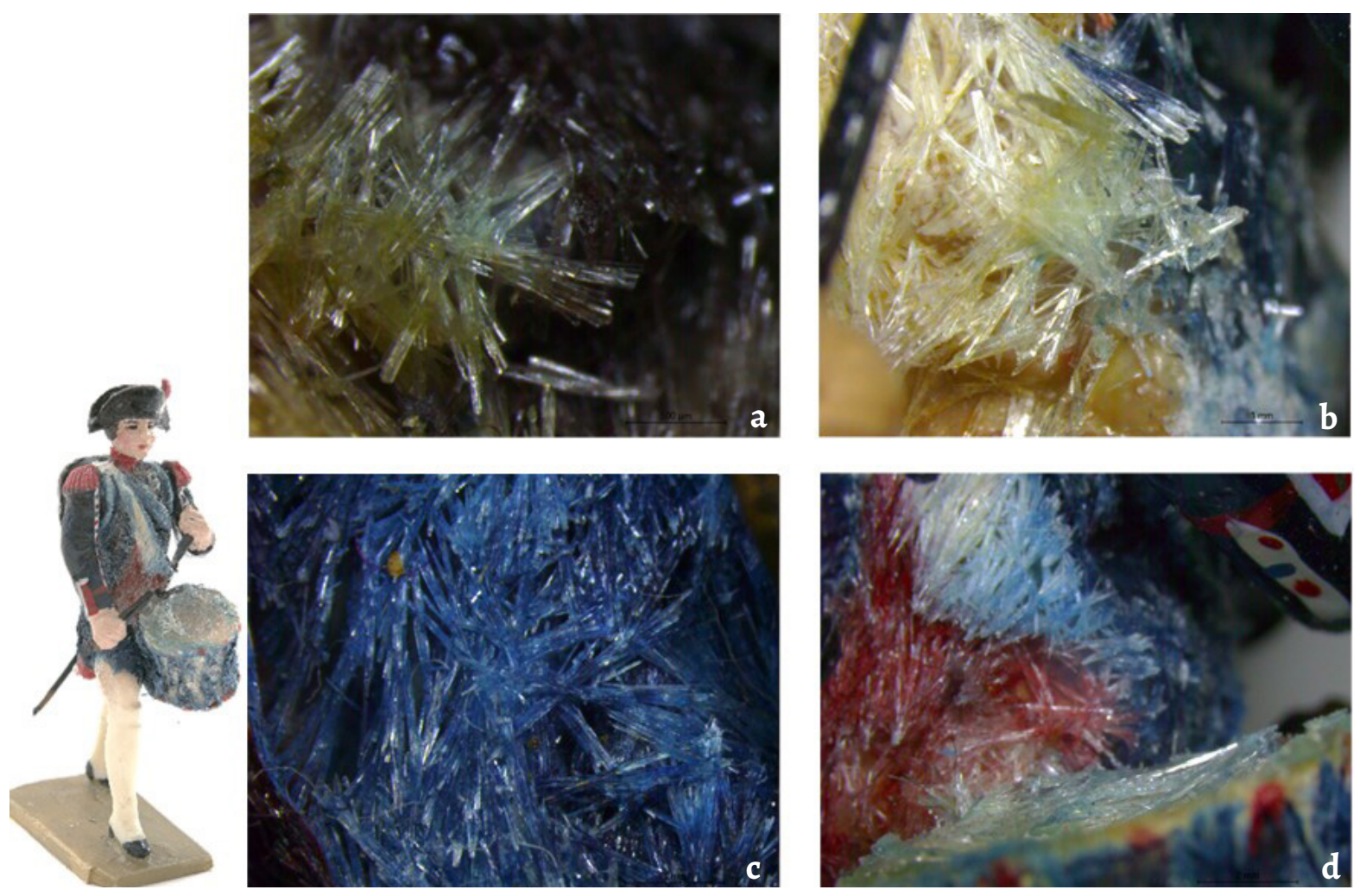

Figure 2. Detail of crystal structures morphology observed by stereozoom microscope directly on the toy soldier figurines: drum $(a, b)$ and jacket $(c, d)$.

deuterated methanol, $\mathrm{CD}_{3} \mathrm{OD}$ (Euriso-top, France). The percolate obtained was immediately placed in a NMR tube for further analysis.

${ }^{1} \mathrm{H}$ and ${ }^{13} \mathrm{C}$ NMR spectra were recorded on a Bruker Avance III HD 400 spectrometer at $400 \mathrm{MHz} .{ }^{1} \mathrm{H}$ shifts are reported relative to the ${ }^{1} \mathrm{H}$ signal of $\mathrm{CH}_{3} \mathrm{OH}(\delta=3.31 \mathrm{ppm})$ reference. ${ }^{13} \mathrm{C}$ shifts are reported relative to the ${ }^{13} \mathrm{C}$ signal of $\mathrm{CH}_{3} \mathrm{OH}$ $(\delta=49.00 \mathrm{ppm})$ reference.

\section{Results and Discussion}

\section{Stereoscopic microscopy (SM) and VP-SEM-EDS}

SM shows that the efflorescences that are protruding from the figurines polymeric structure are colourless and needlelike shape crystals (Figure 2). SEM allowed further insight by allowing to observe that the morphology of the crystals varies from needle-like shape at lower magnifications to prismatic at higher magnifications (Figure 3). EDS analysis reveals that the crystals are essentially composed of carbon (C) and phosphorous (P). Furthermore, SEM-EDS did not reveal any presence of microbial contamination in the surface of the figurines.

\section{ATR-FTIR}

ATR-FTIR is a useful, non-destructive tool capable to identify and classify polymers from a wide range of sources and also some additives.
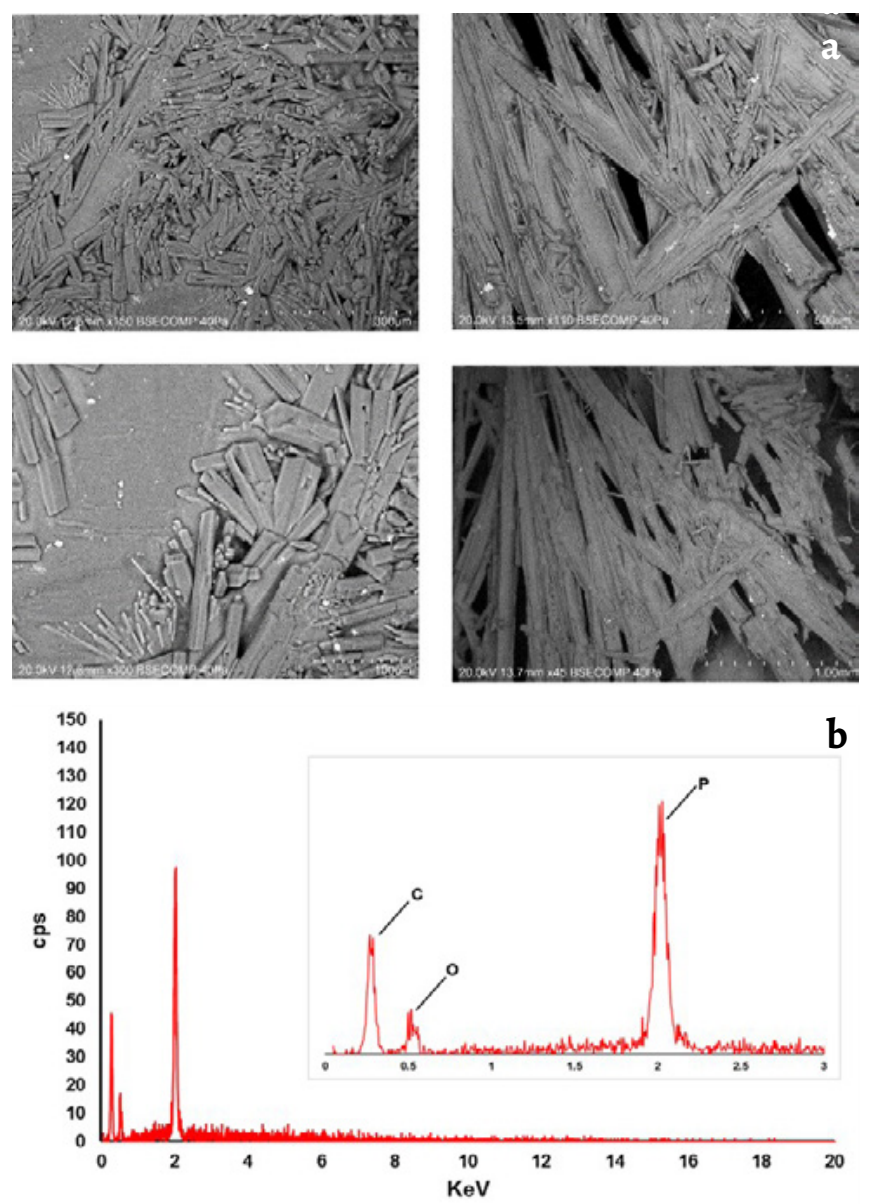

Figure 3. Detail of the crystal structures morphology observed by VP-SEM (in Backscattering mode) (a) and EDS spectrum of the crystals obtained directly on a toy soldier figurine (b). 


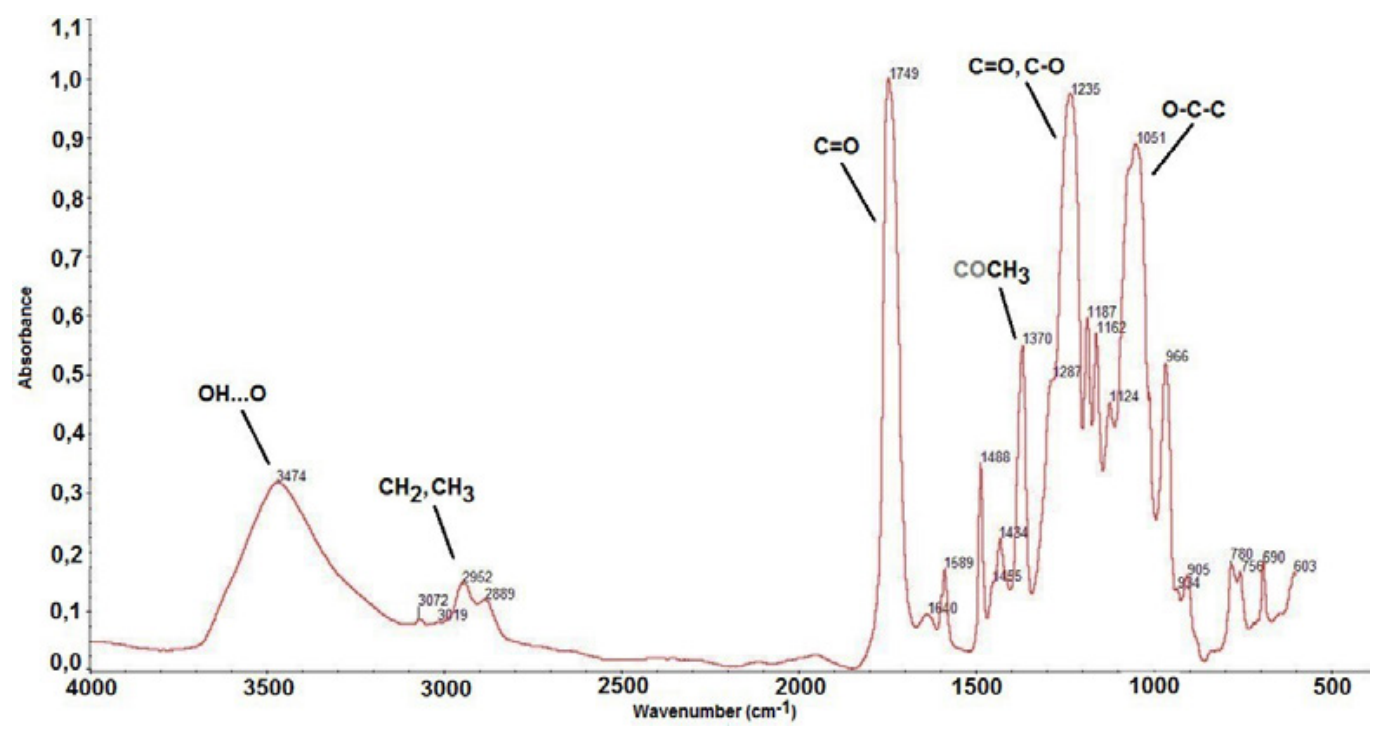

Figure 4. In situ ATR-FTIR spectrum of a toy soldier figurine.

The ATR-FTIR spectrum (Figure 4) shows three strong patterns of bands found in saturated molecules, consistent with cellulose acetate, and typically referred to as "rule of three". The first band at $1749 \mathrm{~cm}^{-1}$ is due to carbonyl stretch of the ester group, while the second band at $1235 \mathrm{~cm}^{-1}$ is due to asymmetric stretching of $\mathrm{C}-\mathrm{C}-\mathrm{O}$ of the ester group. The last large band appearing at $1051 \mathrm{~cm}^{-1}$ is the result of asymmetric O-C-C bond stretching attached to the carbonyl carbon. In addition, smaller bands located at $1370 \mathrm{~cm}^{-1}$ are caused by methyl groups found in acetate esters [22]. Other smaller bands present at 1589,1488,1287, 1187, 1124 and $966 \mathrm{~cm}^{-1}$ suggest the presence of the additives triphenyl phosphate and dimethyl phthalate [31-32]. These additives are common plasticizers for cellulose ester plastics, and the triphenyl phosphate is also used as a flame retardant [2].

\section{Micro-XRD}

X-ray diffraction performed directly on the crystal efflorescence's exhibits the typical XRD pattern of typriphenyl phosphate (indexed reference PDF 26-1882) (Figure 5). These results are in line with the observations by SEM-EDS on the crystals that showed elemental compositions of $\mathrm{C}$ and $\mathrm{P}$ and those by ATR-FTIR, performed on the plastic matrix, which

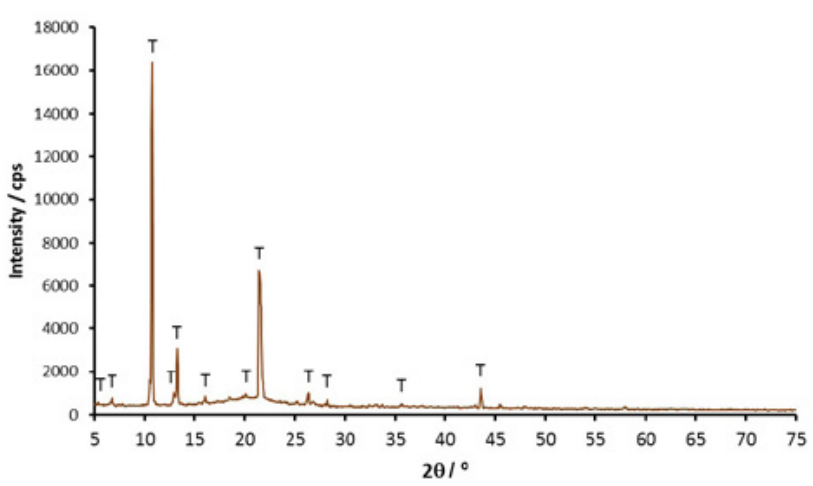

Figure 5. X-ray diffractogram of the crystals: Tindicates triphenyl phosphate. indicated the presence of two distinct additives, namely, triphenyl phosphate and dimethyl phthalate.

Similar crystal structures of triphenyl phosphate have previously been identified in heritage objects as part of the degradation of cellulose acetate $[28,33]$.

\section{NMR}

NMR is a powerful tool that identifies organic molecules, capable of identifying mixtures of polymer additives.

The ${ }^{1} \mathrm{H}$ NMR spectrum of object leachate (Figure 6) clearly presents a mixture of two major organic compounds, namely, triphenyl phosfate and dimethyl phthalate.

Triphenyl phosfate presents three magnetically equivalent groups, with five aromatic protons each, in a system $\mathrm{AA}^{\prime} \mathrm{BB} \mathrm{B}^{\prime} \mathrm{C}$. The two ortho protons, resonate as a multiplet at $\delta=7.23-7.25 \mathrm{ppm}$, the meta protons as a multiplet at $\delta=7.40$ $7.43 \mathrm{ppm}$ and the para proton as also a multiplet at $\delta=7.27$ $7.29 \mathrm{ppm}$.

Dimethyl phthalate presents two doublets of doublets at $\delta=7.62 \mathrm{ppm}$ and $\delta=7.73 \mathrm{ppm}$, in a system $\mathrm{AA}^{\prime} \mathrm{BB}^{\prime}$, assignable

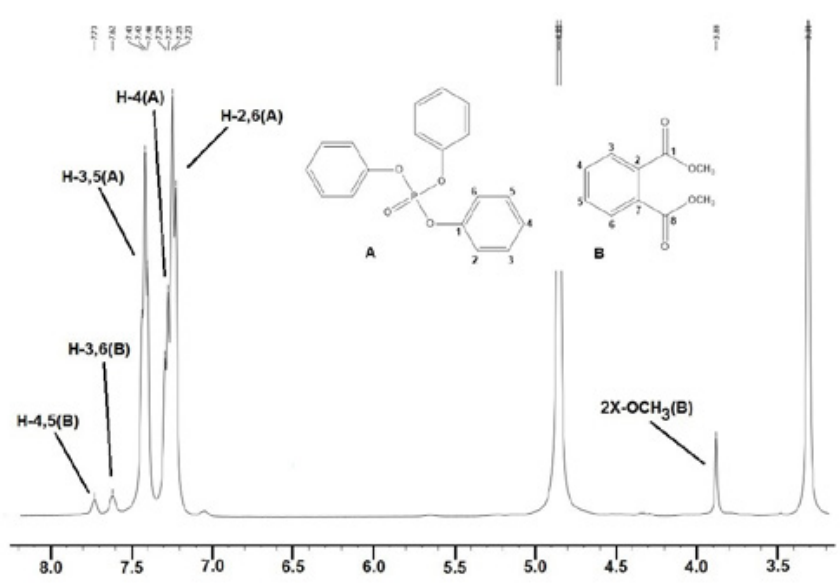

Figure 6. ${ }^{1} \mathrm{H}$ NMR spectrum of object leachate in $\mathrm{CD} 3 \mathrm{OD}$. 
Table 1. ${ }^{1} \mathrm{H}$ and ${ }^{13} \mathrm{C}$ assignments of the additives, triphenylphosfate (A) and dimethyl phthalate (B), in $\mathrm{CD} 3 \mathrm{OD}$.

\begin{tabular}{|c|c|c|c|}
\hline Additive & Position & ${ }^{1} \mathbf{H} \delta$ (ppm) & ${ }^{13} \mathbf{C} \delta$ (ppm) \\
\hline \multirow{6}{*}{ A } & 1 & - & 151.7 \\
\hline & 2 & $7.23-7.25$ & 121.1, 121.2 \\
\hline & 3 & $7.40-7.43$ & 131.2 \\
\hline & 4 & $7.25-7.29$ & 127.2 \\
\hline & 5 & $7.40-7.43$ & 131.2 \\
\hline & 6 & $7.23-7.25$ & $121.1,121.2$ \\
\hline \multirow{5}{*}{ B } & 1,8 & - & 169.7 \\
\hline & 2,7 & - & 133.3 \\
\hline & 3,6 & 7.62 & 129.9 \\
\hline & 4,5 & 7.73 & 132.5 \\
\hline & $2 \times \mathrm{OCH}_{3}$ & 3.88 & 53.2 \\
\hline
\end{tabular}

to four aromatic protons of the phthalate, and a singlet at $\delta=3.88 \mathrm{ppm}$ generated by a methyl group.

All proton assignments are presented in Table 1.

The interpretation of ${ }^{13} \mathrm{C}$ NMR spectrum (Figure 7) allow the unequivocally assignment of all carbon signals (Table $\mathrm{I}$ ), confirming the presence of the additives detected in IH NMR. The ${ }^{13} \mathrm{C}$ NMR technique proved to also be a complementary tool for the polymer additives characterization.

Furthermore, the ${ }^{1} \mathrm{H}$ and ${ }^{13} \mathrm{C}$ NMR spectrum of object efflorescences, Figure 8 and Figure 9 respectively, identify clearly the needle shape crystals as triphenyl phosphate, in a state of high purity.

\section{Conclusion}

The present multi-analytical study allowed the identification of the polymer used for the manufacture of the plastic toys, cellulose acetate, two additives, dimethyl phthalate and triphenyl phosphate, and the identification of a very pure crystallyne efflorescence composed by one of the additives, triphenyl phosphate. The in situ attenuated total reflection-fourier transform infrared spectroscopy (ATR-FTIR) analysis allowed the identification of the polymer nature and the indication of the two additives. The ${ }^{1} \mathrm{H}$ and ${ }^{13} \mathrm{C}$ nuclear magnetic resonance (NMR) analysis allowed an unequivocally identification of the additives and showed the very pure nature of the crystalline efflorescence. The micro-XRD analysis allowed the characterisation of the crystallographic structure of the efflorescence, as triphenyl phosphate. The SM and SEM-EDS analysis allowed the morphological observation of the surfaces. Preventive conservation measures are being undertaken to prevent the fast degradation of this collection, including removal from the museum showcase

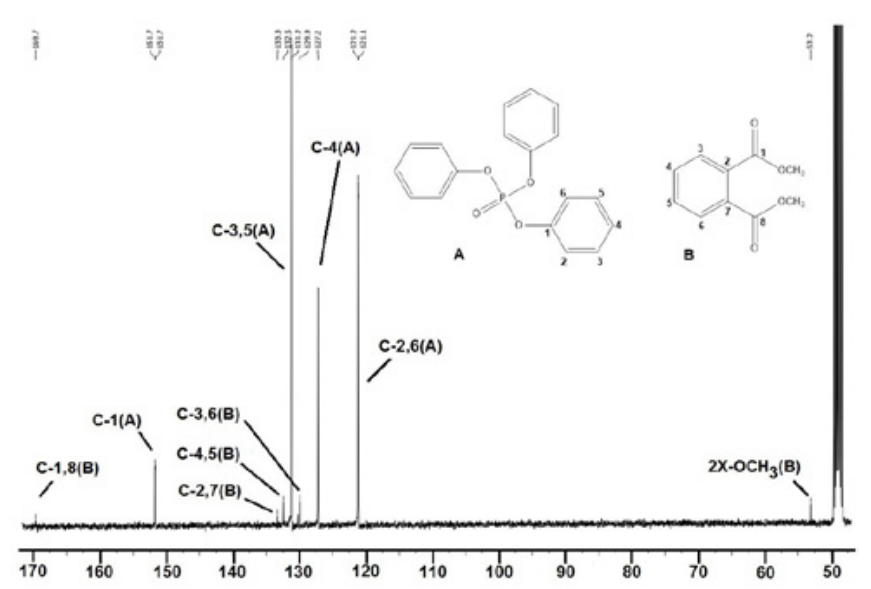

Figure 7. Tasks performed during fieldwork: a) cleaning of structures; b) laser scanning.

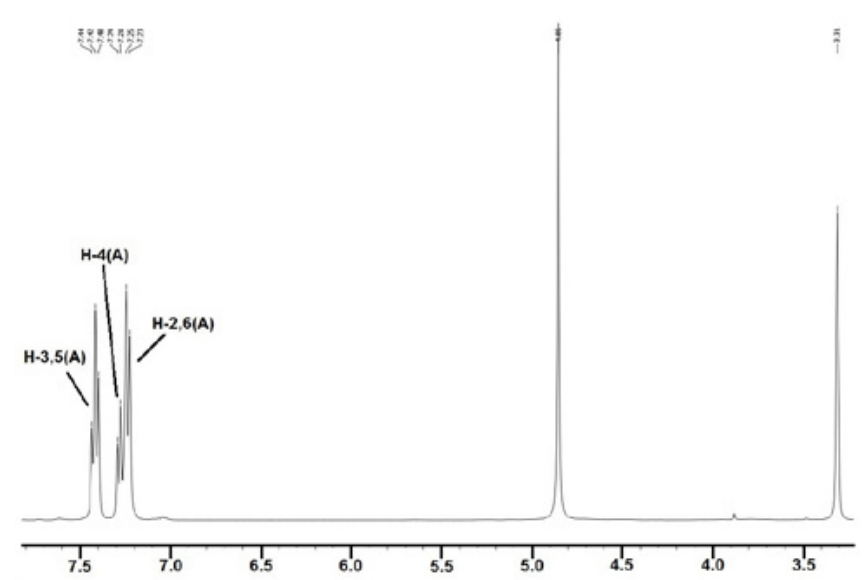

Figure 8. ${ }^{1} \mathrm{H}$ NMR of object efflorescences in $\mathrm{CD} 3 \mathrm{OD}$.

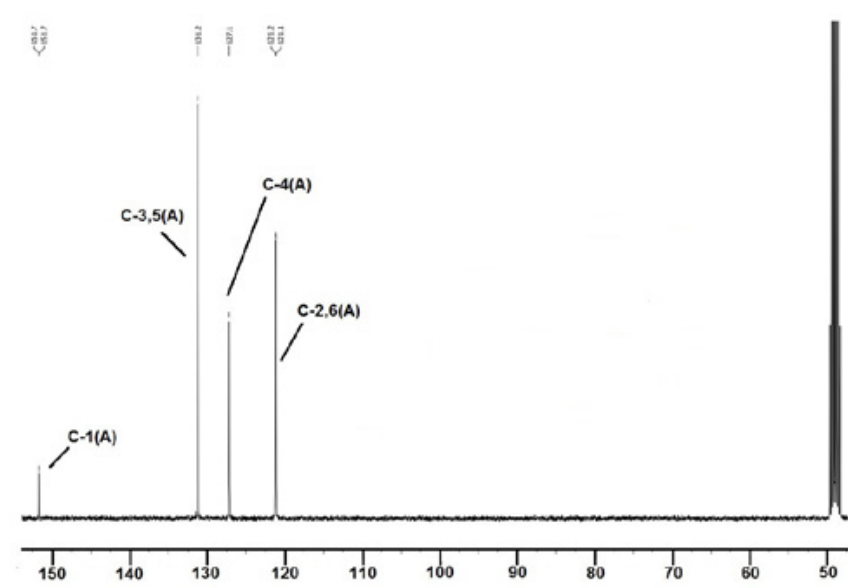

Figure 9. ${ }^{13} \mathrm{C}$ NMR of object efflorescences in $\mathrm{CD} 3 \mathrm{OD}$.

of the toy soldier figurines that present this pathology and study of the optimal microclimatic conditions of the showcase including ventilation and acid vapours adsorbents. 


\section{Acknowledgments}

The authors would like to thank the Oporto Military Museum (Museu Militar do Porto) and project THE SCREAM (POCI-01-0145-FEDER-031577) for the financial support through program POCI-FEDER-Alentejozozo and to the research unit HERCULES Laboratory (grant no. UID/ Multi/04449/2013). The authors fully acknowledge the anonymous reviewers and the editors of the journal by their valuable remarks, comments and corrections to the submitted version of the manuscript, which significantly contributed to the quality of the paper.

\section{REFERENCES}

1. Brydson, J. Plastics materials, 7th ed., Elsevier, ButterworthHeinemann, Oxford (1999).

2. Wypych, G., Handbook of Plasticizers, 2nd ed., ChemTec Publishing, Ontario, Canada, (2012).

3. Rychlý, J.; Matisová-Rychlá, L.; Csomorová, K., 'Degradation of plastics from the ResinKit as a model for the selection of polymers for artworks. Assessment by nonisothermal thermogravimetric analysis and chemiluminometry', Polymer Degradation and Stability 102(1) (2014) 105-111, https://doi. org/10.1016/j.polymdegradstab.2014.01.033.

4. Madden, O.; Learner, T., 'Preserving plastics', The GCI Newsletter 29 (2014) 4-9.

5. Keneghan, B., 'Damage limitation', Materials World 19 (2011) 24-25.

6. Pangallo, D.; Chovanová, K.; Šimonovičová, A.; Ferianc, P., 'Investigation of microbial community isolated from indoor artworks and air environment: identification, biodegradative abilities, and DNA typing', Canadian Journal of Microbiology 55(3) (2009) 277-287 https://doi.org/10.1139/wo8-136.

7. Rosado, T.; Martins, M.R.; Pires, M.; Mirão, J.; Candeias, A.; Caldeira, A.T., 'Enzymatic monitorization of mural paintings biodegradation and biodeterioration', International Journal of Conservation Science 4 (Spe. Issue) (2013) 603-612.

8. Montanari, M.; Melloni, V.; Pinzari, F.; Innocenti, G., 'Fungal biodeterioration of historical library materials stored in Compactus movable shelves', International Biodeterioration \& Biodegradation 75 (2012) 83-88, https://doi.org/10.1016/j. ibiod.2012.03.011.

9. Manso, M.; Cardeira, A. M.; Silva, M.; Gac, A.; Pessanha, S.; Guerra, M.; Caldeira, A. T.; Candeias, A.; Carvalho, M. L., 'The mysterious halos in iron gall ink manuscripts: an analytical explanation', Applied Physics A 118(3) (2015) 1107-1111, https:// doi.org/10.1007/s00339-014-8924-Z.

10. Latini, G., 'Potential hazards of exposure to Di-(2-Ethylhexyl)Phthalate in babies', Biology of the Neonate 78(4) (2000) 269-276, https://doi.org/10.1159/000014278.

11. Hill, S.; Shaw, B.; Wu, H., 'The clinical effects of plasticizers, antioxidants, and other contaminants in medical polyvinylchloride tubing during respiratory and nonrespiratory exposure', Clinica Chimica Acta 304(1-2) (2001) 1-8, https://doi.org/10.1016/s0009-8981(00)00411-3.

12. Brockway, R., 'Safe handling of plastics', Eco Exchange 4(1) (2009) 1-4.

13. Sonnenschein, C.; Soto A., 'An updated review of environmental estrogen and androgen mimics and antagonists', The Journal of Steroid Biochemistry and Molecular Biology 65(1-6) (1998) 143-150, https://doi.org/10.1016/S09600760(98)00027-2.
14. Pourmortazavi, S.; Hosseini, S.; Rahimi, N.; Hajimirsadeghi, S.; Momenian, H., 'Effect of nitrate content on thermal decomposition of nitrocellulose', Journal of Hazardous Materials 162(2-3) (2009) 1141-1144, https://doi.org/10.1016/j. jhazmat.2008.05.161.

15. Rong, L.; Binke, N.; Yuan, W.; Zhengquan, Y.; Rongzu, H., 'Estimation of the critical temperature of thermal explosion for the highly nitrated nitrocellulose using non-isothermal DSC', Journal of Thermal Analysis and Calorimetry 58(2) (1999) 369-373, https://doi.org/10.1023/A:1010155221958.

16. Binke, N.; Rong, L.; Zhengqua, Y.; Yuan, W.; Pu, Y.; Rongzu, H.; Qingsen, Y., 'Studies on the kinetics of the first order autocatalytic decomposition reaction of highly nitrated nitrocellulose', Journal of Thermal Analysis and Calorimetry 58(2) (1999) 403-411, https://doi.org/10.1023/A:1010163423775.

17. Knotková-Cermákova, D.; Vlcková, J., 'Corrosive effect of plastics, rubber and wood on metals in confined spaces', British Corrosion Journal 6(1) (1971) 17-22, https://doi.org/10.1179/ 000705971798324134

18. Lattuati-Derieux, A.; Egasse, C.; Thao-Heu, S.; Balcar, N.; Barabant, G.; Lavédrine, B., 'What do plastics emit? HSSPME and GC/MS analyses of new standard plastics and plastic objects in museum collections', Journal of Cultural Heritage 14(3) (2013) 238-247, https://doi.org/10.1016/j. culher.2012.06.005.

19. Larkin, N.; Blades, N.; Makridou, E., 'Investigation of volatile organic compounds associated with polyethylene and polypropylene containers used for conservation storage', The Conservator 24(1) (2000) 41-51, https://doi.org/10.1080/0141009 6.2000 .9995149 .

20. Shashoua, Y., Conservation of plastics: materials science, degradation and preservation, Routledge, London (2008), https://doi.org/10.4324/9780080878782.

21. Šuštar, V.; Kolar, J.; Lusa, L.; Learner, T.; Schilling, M.; Rivenc, R.; Khanjian, H.; Koleša, D., 'Identification of historical polymers using Near-Infrared Spectroscopy', Polymer Degradation and Stability 107 (2014) 341-347, https://doi. org/10.1016/j.polymdegradstab.2013.12.035.

22. Schilling, M.; Bouchard, M.; Khanjian, H.; Learner, T.; Phenix, A.; Rivenc, R., 'Application of Chemical and Thermal Analysis Methods for Studying Cellulose Ester Plastics', Accounts of Chemical Research 43(6) (2010) 888-896, https://doi.org/10.1021/ ar1000132.

23. Stuart, B., Analytical Techniques in the Sciences: Polymer Analysis, John Wiley \& Sons, Chichester (2002), https://doi. org/10.1002/9780470511343.

24. Learner, T., 'The analysis of synthetic paints by pyrolysis gas chromatography, mass spectrometry (PyGCMS)', Studies in Conservation 46(4) (2001) 225-241, https://doi.org/10.1179/ sic.2001.46.4.225.

25. Pereira, A.; Candeias, A.; Cardoso, A.; Rodrigues, D.; Vandenabeele, P.; Caldeira, A. T., 'Non-invasive methodology to identify plastic objects in museum environment - a novel approach', Microchemical Journal 124 (2016) 846-855, https://doi. org/10.1016/j.microc.2015.07.027.

26. Pereira, A.; Caldeira, A. T.; Maduro, B.; Vandenabeele, P.; Candeias, A., 'Tortoiseshell or Polymer? Spectroscopic Analysis to Redefine a Purported Tortoiseshell Box with Gold Decorations as a Plastic Box with Brass', Applied Spectroscopy 
70(1) (2016) 68-75, https://doi.org/10.1177/0003702815615344.

27. Puls, J.; Wilson, S.; Hölter, D., 'Degradation of cellulose acetate-based materials: a review', Journal of Polymers and the Environment 19 (2011) 152 -165, https://link.springer.com/ article/10.1007/s10924-010-0258-0.

28. McGath, M., 'Investigation of Deterioration Mechanisms of Cellulose Acetate Compounded with Triphenyl Phosphate', Ph.D. Thesis, Department of Materials Science and Engineering, The University of Arizona (2012).

29. Littlejohn, D.; Pethrick, R.; Quye, A.; Ballany, J., 'Investigation of the degradation of cellulose acetate museum artefacts', Polymer Degradation and Stability 98(1) (2013) 416-424, https:// doi.org/10.1016/j.polymdegradstab.2012.08.023.

30. May, E.; Jones, M., Conservation Science: Heritage Materials, Royal Society of Chemistry, Cambridge (2006), https://doi. org/10.1039/9781847557629.

31. Silverstein, R.; Webster, F.; Kiemle, D., Spectrometric Identification of Organic Compounds, 8th ed., John Wiley and Sons, New York (2014).
32. Spectral Database for Organic Compounds, SDBS, https:// sdbs.db.aist.go.jp/ (acesso em 2019-12-10).

33. Tsang, J.;Madden, O., Coughlin, M.; Maiorana, A.; Watson, J.; Little, N.; Speakman, R., 'Degradation of 'Lumarith' Cellulose Acetate: Examination and Chemical Analysis of a Salesman's Sample Kit', Studies in Conservation 54 (2) (2009) 90-105, https:// www.tandfonline.com/doi/abs/10.1179/sic.2009.54.2.90.

RECEIVED: 2020.01 .10

REVISED: 2020.11 .02

ACCEPTED: 2020.12.09

ONLINE: 2020.12 .15

\section{(c) (1) (3)}

This work is licensed under the Creative Commons Attribution-NonCommercial-NoDerivatives 4.0 International License. To view a copy of this license, visit

http://creativecommons.org/licenses/by-nc-nd/4.o/deed.en. 